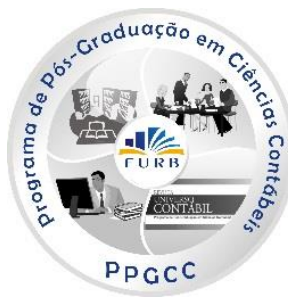

\title{
BOOK-TAX DIFFERENCE, EARNINGS MANAGEMENT AND BOND RATINGS IN THE BRAZILIAN MARKET ${ }^{1}$
}

\section{BOOK-TAX DIFFERENCE, GERENCIAMENTO DE RESULTADOS E RATINGS DE DEBENTURES NO MERCADO BRASILEIRO}

\section{BOOK-TAX DIFFERENCE, MANIPULACÍON CONTABLE Y RATING DE OBLIGACIONES EN EL MERCADO BRASILEÑO}

\author{
Diego Lopes Miiller \\ Mestre em Contabilidade Gerencial e Tributária \\ Endereço: Avenida Fernando Ferrari, 1358 - Boa Vista \\ CEP: 29075-505 - Vitória - ES - Brasil \\ E-mail: dc.contabilidademiiller@gmail.com \\ Telefone: +55 (27) 40094444
}

Antônio Lopo Martinez

Doutor em Controladoria e Contabilidade pela FEA/USP Professor e Pesquisador da Fundação Instituto Capixaba de Pesquisa em Contabilidade, Economia e Finanças Endereço: Avenida Fernando Ferrari, 1358 - Boa Vista CEP: 29075-505 - Vitória - ES - Brasil

E-mail: lopo@fucape.br Telefone: +55 (27) 40094444

\begin{abstract}
This article investigates whether the credit rating of bond issues in the Brazilian market is influenced by the differences between book income and taxable income (BTD), as well earning management practices, based on a sample of all nonfinancial firms that issued bonds in the period from 2004 to 2014 with published financial information, resulting in a final sample of 96 observations. The results indicate BTD does not determine the credit rating in the Brazilian market. Additionally, we tested the influence on credit rating of propensity for earnings management (EM) and tax management (TM). The results indicate as earnings management increases, ratings tend to decline, while firms that engage in aggressive tax management are not penalized. The study of this phenomenon can help to predict the credit rating in Brazil, and would allow identifying factors that affect it and actions to reduce the perception of risks to solvency, and consequently the cost of debt.
\end{abstract}

\footnotetext{
${ }^{1}$ Artigo recebido em 10.112015. Revisado por pares em 06.03.2016. Reformulado em 30.08.2016. Recomendado para publicação em 20.09.2016 por Paulo Roberto da Cunha. Publicado em 27.09.2016. Organização responsável pelo periódico: FURB.
} 
Keywords: Book-tax differences; Earnings management; Bonds; Rating.

\section{Resumo}

O presente estudo investigou se o rating de crédito na emissão de debênture no mercado brasileiro é determinado em parte pelas diferenças entre o lucro contábil e tributário (BTD), bem como práticas de gerenciamento de resultados. Esta relação foi realizada mediante estudo de todas empresas que emitiram debêntures no período de 2004 a 2014 e que dispõem das informações financeiras publicadas, exceto as empresas financeiras, resultando em uma amostra final de 96 observações. Os resultados indicam que a BTD não determina o rating de crédito no mercado brasileiro. Adicionalmente, foi testada a determinação do rating de crédito pela propensão ao gerenciamento de resultado (EM) contábil e o tributário (TA). Os resultados indicaram que as empresas que gerenciam o seu resultado contábil para aumentá-lo são penalizadas com um rebaixamento, ao passo que as empresas propensas a um planejamento tributário mais agressivo não são penalizadas. O estudo deste fenómeno pode ajudar a estimar o rating de crédito no Brasil, e permitir identificar os fatores que o afetam e as ações para reduzir a percepção de riscos para a solvência e, consequentemente, o custo da dívida.

Palavras Chave: Diferença entre lucro contábil e tributário; Gerenciamento de resultado contábil; Debêntures; Ratings.

\section{Resumen}

Este estudio investigó si la calificación crediticia de la emisión de obligaciones en el mercado brasileño está determinada en parte por las diferencias entre el resultado contable y tributaria (BTD) y practicas de earnings management. Esta relación fue realizado por el estudio de todas las empresas que han emitido bonos 2004-2014 y que tengamos la información financiera publicada, excepto las sociedades financieras, lo que resulta en una muestra final de 96 observaciones. Los resultados indican que BTD no determina la calificación crediticia en el mercado brasileño. Además, se puso a prueba la determinación de la calificación crediticia de la propensión a gestión de resultados (GI) contable y planeamiento tributario (TA). Los resultados indicaron que las empresas a gestionar su valor en libros para aumentarla se penalizada con la rebaja, mientras que las empresas con tendencia a la gestión tributaria no son penalizados. El estudio de este fenómeno puede ayudar a predecir la calificación de crédito en Brasil, y permitiría la identificación de los factores que la afectan y las acciones para reducir la percepción de los riesgos para la solvencia, y por lo tanto el costo de la deuda.

Palabras clave: Diferencia entre la contabilidad y la utilidad fiscal; Gestión de resultados, Obligaciones, Rating.

\section{INTRODUCTION}

This article examines whether bond credit ratings in the Brazilian market are influenced by the differences between book income and taxable income, or book-tax differences, as well for earnings management practices. The credit rating expresses the opinion of a particular rating agency on the capacity and predisposition of a firm to meet its financial obligations fully and timely (STANDARD \& POOR'S, 2011).

Many studies (HAND; HOLTHAUSEN and LEFTWICH 1992; ZIEBART; RIETER 1992; BLUME, LIM and MACKINLAY 1998; CHENG and SUBRAMANYAM 2008) have found evidence that agencies use both public and private financial information, and this information directly affects the credit rating.

Ahmed, Billings, Morton and Stanford-Harris (2002) found the credit rating is positively associated with accounting conservatism, i.e., more conservative firms tend to have higher credit ratings. Additionally, Francis et al. (2005) demonstrated the rating is positively associated with the quality of accruals. 
In this respect, the book-tax difference can be broken down into two portions: the nondiscretionary part of the permanent differences between the financial numbers according to tax and accounting rules (NBTD - normal book-tax differences); and the discretionary part of those differences (ABTD - abnormal book-tax differences). This second portion can be caused by earnings management (EM) and tax management (TM).

Tang (2006), Formigoni, Antunes and Paulo (2009) and Martinez and Passamani (2014) have all presented evidence that ABTD is a proxy for the quality of earnings, since it indicates managers are trying to increase the accounting income and reduce the taxable income (Ferreira et al., 2012). Therefore, the rating agencies' analysts can interpret BTDs as an indication of reduced quality of earnings, thus posing a risk factor to the target firm's solvency, prompting them to lower the credit rating (AYRES, LAPLANTE and MCQUIRE, 2010).

The study of this phenomenon is relevant due to the internationalization of the financial markets and the growing diversification of the sources of capital. Therefore, a model can help predict the credit rating would allow identifying factors that affect it and actions to reduce the perception of risks to solvency, and consequently the cost of debt (KIM and GU, 2004; GRAY, MIRKOVIC and RAGUNATHAN, 2006). Another factor makes this study relevant is the absence of studies of the effect of book-tax differences on ratings in the Brazilian market. Therefore, our research question is the following: Can the credit rating of bond issues in the Brazilian market be explained in part by book-tax differences?

The article is organized into five sections including this introduction. In the second section we briefly review the relevant literature and present our two research hypotheses. In the third section we present the methodology and propose the regression models. In the fourth section we analyze the results, before presenting our conclusions and suggestions for future research in the fifth section.

\section{THEORETICAL FOUNDATION}

Here we review the concepts and contributions in the literature on the informative potential of book-tax differences, and summarize some important previous findings on the use of this information by rating agencies.

\subsection{Information contained in book-tax differences \\ 2.1.1 Book-tax differences}

Book-tax differences occur because of the different standards for reporting accounting income, tailored to meet the needs of investors and other users according to generally accepted accounting principles - GAAP (in Brazil via pronouncements from the Accounting Pronouncements Committee-CPC, along with Laws 11,638/2007 and 11,941/2009 and various resolutions from the Federal Accounting Council - CFC), and the rules imposed by the tax authorities, which rely on the GAAP structure with the adjustments determined by tax legislation.

In Brazil, there are two levies on profits, both at the federal level. The first is Corporate Income Tax (IRPJ) and the second is Social Contribution on Net Profit (CSLL). There are also four different tax regimes, basically depending on firm size: real profit (for large firms), presumed profit (for midsize companies), arbitrated profit (only used at the imposition of the tax administration when there is a lack of information or in rare cases at the behest of the firm), and Simples Nacional (for micro and small enterprises).

The firms in our sample were all subject to the real profit regime during the study period. Under this regime, IRPJ and CSLL are calculated based on the accounting income as determined by corporate legislation, adjusted by the additions and exclusions defined by tax legislation (namely articles 249 and 250 of Decree 3,000/1999, better known as the Income Tax 
Regulation). The IRPJ rate is $15 \%$ plus a surcharge of $10 \%$ on annual profit over $\mathrm{R} \$ 240,000.00$, and the CSLL rate is $9 \%$, so the effective income tax rate for the majority of large firms is $34 \%$, the figure assumed in this study.

In 2008, as part of the process of harmonizing local accounting practices to International Financial Reporting Standards (IFRS), initiated by Law 11,638/2007, Provisional Measure $449 / 2008$ was issued (converted into Law 11,941/2009). Among other matters, this created the "transitional taxation regime" (RTT), to assure the effects of accounting convergence would not have tax impacts, with the rules as of December 31, 2007 remaining valid, so as to neutralize the effect of the accounting procedures and rules brought by the new corporate legislation. The RTT generally caused a greater gap between book income and taxable income starting in 2007, but it was revoked in 2013 by Provisional Measure 627, converted into Law 12,973 in 2014.

The two standards give rise to differences with permanent characteristics, i.e., when revenues or expenses in a period are only recognized for accounting purpose, and temporary differences, when transactions are recorded for both accounting and tax purposes, but in different periods (MARTINEZ and PASSAMANI, 2014). Therefore, temporary differences between book and taxable income (TBTD) are characterized by deferred recognition of taxable income, and hence of taxes. These can either be positive (higher accounting than taxable income) or negative (lower book than taxable income) (HANLON, 2005).

According to the classification in the literature, the permanent differences caused by the mismatch between accounting and tax rules compose the nondiscretionary portion of BTD (NBTD - normal book-tax differences) while the discretionary part of BTD (ABTD - abnormal book-tax differences) can be caused by earnings management (EM) and tax management (TM) (TANG, 2006; FORMIGONI, ANTUNES and PAULO, 2009; MARTINEZ and PASSAMANI, 2014).

\subsubsection{Informative potential of BTD}

As noted by Ferreira (2012), BTD has been a recurrent topic in the recent business literature, due to its relevance to the two most important users of accounting information, the government and shareholders (Shackel-Ford and Shevlin, 2001; Hanlon and Heitzman, 2010; Graham, Raedy and Shackelford, 2012). Additionally, Hanlon and Heitzman (2010) state BTD is an important and promising topic in international studies of taxation.

In this respect, some international and Brazilian studies in the recent literature related to various aspects of the informational content of BTD can be mentioned, such as the persistence of earnings (PHILLIPS et al., 2003; HANLON, 2005; BLAYLOCK et al., 2012; MARTINEZ and SOUZA, 2015), earnings and tax management (TANG, 2006; FORMIGONI, ANTUNES and PAULO, 2009), profit growth (JACKSON, 2009), prediction of bankruptcy (SCHNADER and NOGA, 2013) and credit analysis (AYRES, LAPLANTE and McGUIRE, 2010).

Among these studies, we highlight the analysis of the deterioration of earnings quality of firms that present large BTDs, since managers have incentives to maximize book income and reduce taxable income (FERREIRA et al., 2012).

According to Hanlon and Heitzman (2010), BTD is a relevant indicator of the earnings quality, as revealed by associations between firms' current and future results. An extensive literature suggests BTD contributes to the risk of reduced earnings quality (NOGA \& SCHNADER, 2013), in which firms that present large BTDs have less persistent profits (PHILLIPS et al., 2003; HANLON, 2005; BLAYLOCK et al., 2012).

In this respect, Hanlon (2005) examined BTD as an indicator of the persistence of earnings, accruals and cash flow, and also assessed the evaluation of investors about the predictability of future results. She used data covering the period from 1994 to 2000 on 4,050 firms, for total of 14,106 firm-years. She concluded companies in the sample with large BTDs 
disclosed less persistent profits compared to firms with small BTDs, and also investors interpret the profits of the former firms as a "red flag" to reduce their expectations about future profits.

Jackson (2009) examined the relationship between profit growth and BTD, dividing it into its two components (ABTD and NBTD), and tested the relationship of these components with changes in net profits as well as changes in pre-tax profits and tax costs. The author found large differences between accounting and taxable income indicate low quality and less persistence of earnings. Additionally, it was observed slower growth of profits of firms with large BTDs due to earnings management.

Tang (2006) investigated the potential of BTD to reveal earnings and tax management, by testing the associations between ABTDs and incentives for earnings and tax management. The results showed firms with large incentives and propensity for earnings management presented high ABTD levels, making it a good proxy to analyze the management of accounting and tax information after controlling for NBTD.

In the context of credit analysis, Ayers, Laplante and McGuire (2010) studied the interpretation of credit analysts about the information contained in BTDs and detected both positive and negative book-tax differences (PBTDs and NBTDs respectively) result in less favorable ratings. In other words, variations in BTDs are taken as a negative signal by ratings agencies. But they also found the propensity for tax management tends to attenuate rating downgrades.

With respect to the use of the information contained in BTD to forecast bankruptcy, Schnader and Noga (2013) investigated the association between changes in ABTD and the predictability of bankruptcy, concluding that this information significantly increases the probability of bankruptcy, so it can be used as a tool to identify firms that are more likely to go bust.

The Brazilian literature contains only a few studies related to BTD, such as Formigoni, Antunes and Paulo (2009), Ferreira et al. (2012), Machado and Nakao (2012), Martinez and Passamani (2014) and Martinez and Souza, (2015). Among these, we can highlight the work of Formigoni, Antunes and Paulo (2009), who analyzed the composition of BTD to identify and explain whether this difference tends to be the result of earnings management and/or tax management. However, they did not find a statistically significant relation between the two practices and BTD.

Therefore, following the footsteps of Ayres, Laplante and McGuire (2010), our aim here is to investigate the impact of the informative potential of BTD, as evidenced in the literature, and also of earnings and tax management, on external users, in particular the credit ratings of bond issues assigned by rating agencies.

\subsection{The debt market and credit ratings}

According to the National Association of Financial Market Institutions (Andima, 2008, p. 50), bonds are defined as a security issued by a corporation, representing a fraction of a loan (Law 6,385/76, art. 2, I) originating from a loan contract between the issuing company and the purchasers (bondholders, represented by a fiduciary agent), that grants to the latter a credit right against the former, according to the indenture and certificate (Law 6,404/76, art. 52).

The issuing company can make one or more issues -each possibly divided into series, with those of the same series having equal nominal value and conferring the same rights on their holders (Law 6,404/76, art. 53). In Brazil, issuance of bonds has been the main source of funding in the capital market since the economic stabilization in 1994 (Real Plan), a trend was particularly evident in 2005 and 2006 (PIMENTEL, PERES \& LIMA, 2011). According to those authors, most of the money raised through bond issues in the period from 1995 to 2009 was by leasing companies, which accounted for $63.4 \%$ of the total. 
Nevertheless, Pimentel et al. (2008) identified various factors preventing greater development of the domestic bond market, among them a relatively unreliable accounting and auditing system and low efficiency in predicting insolvency and assigning credit ratings.

With respect to credit ratings, starting in 2001 it became increasingly common for firms to retain rating agencies to classify their placements of securities, in response to Resolutions 2,720/00 and 2,829/00 from the National Monetary Council (CMN), requiring "low credit risk" ratings of bonds held in the portfolios of private pension funds (ANDIMA, 2008). Furthermore, in this respect, the growing internationalization of markets and consequent diversification of the forms and sources of funding have also increased the need for favorable ratings from respective agencies, to enable Brazilian firms to raise money in the foreign debt markets.

Rating agencies issue classifications for both corporate and sovereign debt. In the corporate case, the agencies express an opinion on the capacity and disposition of the issuing firm to meet its financial obligations timely (Standard \& Poor's, 2011). Likewise, the sovereign credit rating is an estimate of the issuing government's capacity to honor its debts, over the long term (FITCH RATINGS, 2012).

The credit ratings by the main agencies are denoted by letter symbols, indicating the categories used by Standard \& Poor's, Moody's and Fitch. However, to demonstrate firms' capacity to honor their financial commitments, Standard \& Poor's and Fitch use 22 different ratings, while Moody's uses 21, as shown in Table 1.

Table 1 - Ordinal classification of the ratings attributed by the main agencies

\begin{tabular}{|c|c|c|c|c|}
\hline & $\mathbf{S \& P}$ & FITCH & MOODY'S & ORDINAL CLASSIFICATION \\
\hline \multirow{10}{*}{ 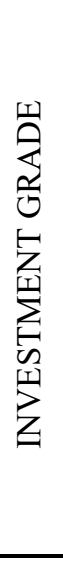 } & AAA & AAA & Aaa & 22 \\
\hline & $\mathrm{AA}+$ & $\mathrm{AA}+$ & Aal & 21 \\
\hline & AA & $\mathrm{AA}$ & $\mathrm{Aa} 2$ & 20 \\
\hline & AA- & AA- & $\mathrm{Aa} 3$ & 19 \\
\hline & $\mathrm{A}+$ & $\mathrm{A}+$ & A1 & 18 \\
\hline & $\mathrm{A}$ & $\mathrm{A}$ & A2 & 17 \\
\hline & A- & A- & $\mathrm{A} 3$ & 16 \\
\hline & $\mathrm{BBB}+$ & $\mathrm{BBB}+$ & Baal & 15 \\
\hline & BBB & BBB & Baa2 & 14 \\
\hline & BBB- & BBB- & $\mathrm{Baa} 3$ & 13 \\
\hline \multirow{12}{*}{ 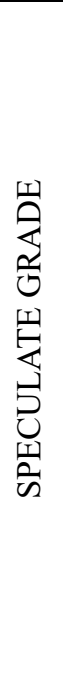 } & $\mathrm{BB}+$ & $\mathrm{BB}+$ & $\mathrm{Ba} 1$ & 12 \\
\hline & $\mathrm{BB}$ & BB & $\mathrm{Ba} 2$ & 11 \\
\hline & BB- & BB- & $\mathrm{Ba} 3$ & 10 \\
\hline & $\mathrm{B}+$ & $\mathrm{B}+$ & B1 & 9 \\
\hline & $\mathrm{B}$ & $\mathrm{B}$ & B2 & 8 \\
\hline & B- & $\mathrm{B}-$ & B3 & 7 \\
\hline & $\mathrm{CCC}+$ & $\mathrm{CCC}+$ & Caa1 & 6 \\
\hline & $\mathrm{CCC}$ & $\mathrm{CCC}$ & $\mathrm{Caa} 2$ & 5 \\
\hline & CCC- & CCC- & $\mathrm{Caa} 3$ & 4 \\
\hline & $\mathrm{CC}$ & $\mathrm{CC}$ & $\mathrm{Ca}$ & 3 \\
\hline & $\mathrm{C}$ & $\mathrm{C}$ & $\mathrm{C}$ & 2 \\
\hline & $\mathrm{D}$ & $\mathrm{D}$ & & 1 \\
\hline
\end{tabular}

Source: Prepared by the authors. 


\subsection{Utilization of accounting information in credit rating}

\subsubsection{Credit rating agencies and their role in the solvency of the market}

Since the end of the 1980s the demand for information related to credit analysis has grown drastically in the international financial market, prompting the development of many methods for this purpose (Callado et al., 2008). Therefore, the importance of the credit rating agencies has grown commensurately (CALDERONI, COLLA \& GATTI, 2009).

From the standpoint of firms, the credit rating has great practical importance, since it has a direct impact on their cost of debt, financial structure and capacity to continue placing debt securities (GRAY et al., 2006).

From the market's viewpoints, credit rating agencies play an important role in complementing the systems to evaluate solvency, in particular the examination and monitoring activities of investment analysts and providers of corporate debt (ADAMS et al., 2003).

In the Brazilian context, the importance of credit rating agencies is not as great, but their role has been growing, especially as the country gains relevance in the global economy. Therefore, the Brazilian market presents a scenario propitious for studies related to credit ratings (MURCIA, MURCIA \& BORBA, 2014).

In view of the large importance of ratings in the solvency of the international financial market, studies of the possible information used to assign credit ratings have informative potential for the agents involved in credit transactions, since according to Kim and $\mathrm{Gu}$ (2004), a model able to predict a firm's rating would enable identifying the factors that affect those ratings, allowing actions to reduce the risk perception and hence the cost of debt.

However, it is not possible to know all the variables employed by the agencies in determining their ratings. Although they all publish general guides to evaluate their ratings, they never provide details about the financial variables are most important (KIM \& GU, 2004).

In a recent study of the determinants of credit ratings in the Brazilian market, Murcia, Murcia and Borba (2014) identified five relevant classes of variables, which are listed below in Chart 1, together with the studies that attest to their significance.

Chart 1 - Significant determinants of credit ratings in the Brazilian market

\begin{tabular}{|c|c|}
\hline DETERMINANT & $\begin{array}{c}\text { STUDIES HAVE DEMONSTRATED THE SIGNIFICANCE } \\
\text { OF THE DETERMINANT }\end{array}$ \\
\hline Leverage & $\begin{array}{c}\text { Adams, Burton and Hardwick (2003); Gray, Mirkovic and } \\
\text { Ragunathan (2006); Damasceno, Artes and Minardi (2008); Shiu } \\
\text { e Chiang (2008); }\end{array}$ \\
\hline Profitability & $\begin{array}{l}\text { Bouzouita e Young (1998); Adams, Burton and Hardwick } \\
\text { (2003); Kim and Gu (2004); Gray, Mirkovic and Ragunathan } \\
\text { (2006); López (2007); Damasceno, Artes and Minardi (2008); } \\
\text { Shiu and Chiang (2008); Matousek and Stewart (2009); }\end{array}$ \\
\hline Sales Growth & Bouzouita and Young (1998); Shiu and Chiang (2008); \\
\hline Financial Market Performance & Murcia (2014) \\
\hline Internationalization & Murcia (2014) \\
\hline
\end{tabular}

Source: Adapted from Murcia, Murcia and Borba (2014).

\subsubsection{Credit ratings and book-tax differences}

In assigning credit ratings, the agencies use different methods. Some focus only on quantitative data while others also consider qualitative information, obtained through meetings with representatives of firms or governments (STANDARD \& POOR'S, 2011). 
The first studies of the use of quantitative data obtained from accounting reports date from the 1960s (DAMASCENO, 2008). Since then, many papers have investigated the use of accounting information by rating agencies, analyzing various accounting metrics, such as the capacity to pay interest (interest coverage), percent of financing of assets, profitability and firm size. Rating agencies use all these metrics in their analyses (AYRES, LAPLANTE \& MCGUIRE, 2010).

More specifically, studies like Hand, Holthausen and Leftwich (1992), Ziebart and Rieter (1992), Blume, Lim and Mackinlay (1998), and Cheng and Subramanyam (2008) have found agencies use both public and private information, and that financial information directly affects the credit rating.

According to Ahmed, Billings, Morton and Stanford-Harris (2002), the credit rating is positively associated with accounting conservatism, i.e., more conservative firms tend to obtain higher credit ratings. Additionally, Francis et al. (2005) demonstrated the rating is positively associated with the quality of accruals.

In this respect, since BTD is a proxy for the earnings quality, users of accounting information can interpret it as a risk factor in estimating the solvency of firms, making it a variable that potentially influences credit ratings in the Brazilian market.

However, according to Weber (2009), the market tends to underestimate the risks involved in high BTDs, so this metric is not correctly priced, even though other studies on credit ratings have validated the utility of BTD in forecasting financial difficulties.

No previous studies have analyzed the use of the information contained in BTD in determining credit ratings in the Brazilian market, although some recent works have used this metric in their models of accounting information quality, such as Brito and Neto (2008), Damasceno, Arte and Minard (2008), Paulo, Calvacante and Melo (2012), and Fernandino, Takamatsu and Lamounier (2014).

Among these we highlight the study by Fernandino, Takamatsu and Lamounier (2014), who evaluated the influence of accounting indexes on the predictability of the credit ratings of listed Brazilian corporations issued by Fitch Ratings. Their regression models obtained a satisfactory level of significance, especially the variables size and return on assets.

Therefore, the literature discussed on BTDs and credit ratings presents strong indications of this association in the Brazilian market. In other words, rating agencies' analysts can use this information in determining the credit rating, leading to our first hypothesis: BTD.

$\mathbf{H}_{1}$ - The credit rating of bond issues in the Brazilian market can be partly explained by

In light of the division of BTD into two parts, discretionary (ABTD - abnormal booktax differences), which can be caused by earnings management (EM) and/or tax management (TM) (TANG, 2006; FORMIGONI, ANTUNES \& PAULO, 2009; MARTINEZ \& PASSAMANI, 2014), the propensity to engage in earnings management and tax management can be utilized by agencies in attributing credit ratings to bond issues. This leads to our second hypothesis:

$\mathbf{H}_{2}$ - The credit rating of bond issues is partly explained by the propensity to engage in earnings and tax management practices.

\section{METHODOLOGY}

Our objective is to analyze the behavior of the credit ratings of bond issues in the Brazilian market, by analyzing the variables identified in the literature. Hence, this study can be classified as explanatory and descriptive, according to the criteria of Gil (2008). Regarding 
methodology, it is quantitative, since it involves the collection and treatment of quantitative data for the purpose of validating or invalidating a scientific question.

\subsection{Development of the econometric models}

\subsubsection{Model 1 - Book-tax differences as determinants of credit ratings}

To test $\mathrm{H}_{1}$ we applied an econometric model in which the independent variable is the credit ratings announced on the issuance of bonds (Rating $g_{t}$ ) and the dependent variable of interest is the differences between book and taxable income $\left(\mathrm{BTD}_{\mathrm{t}-1}\right)$. Murcia et al. (2014) found five variables with a significant effect on the determination of the credit rating in the Brazilian market, namely: financial leverage $\left(\mathrm{LEV}_{\mathrm{t}-1}\right)$, profitability $\left(\mathrm{PROF}_{\mathrm{t}-1}\right)$, sales growth $\left(\mathrm{GROW}_{\mathrm{t}-1}\right)$, financial market performance $\left(\mathrm{PERF}_{\mathrm{t}-1}\right)$ and level of internationalization (INTER $\left.\mathrm{I}_{\mathrm{t}-1}\right)$. We also used these as control variables, along with size, measured by the natural logarithm of total assets $\left(\log \mathrm{A}_{\mathrm{t}-1}\right)$, and Brazil's investment grade rating $\left(\mathrm{BIG}_{\mathrm{t}-1}\right)$.

The Brazilian investment grade variable $\left(\mathrm{BIG}_{\mathrm{t}-1}\right)$ is necessary because in 2008 Brazil for the first time in its history received this rating from the main agencies, and this level was maintained until the end of our sample period. This means as of that moment, Brazil was among the countries with the lowest perceived risk of default on sovereign debt, making it a favorable destination for investments, with a positive reflection on the credit ratings of Brazilian firms.

Therefore, to analyze the influence of BTD on the credit rating of Brazilian firms, we used the following model:

$$
\begin{aligned}
\text { Rating }_{i t}=\beta_{0}+\beta_{1} B T D_{i t-1}+ & \beta_{2} \log A_{i t-1}+\beta_{3} B I G_{i t-1}+\beta_{4} L E V_{i t-1}+\beta_{5} P R O F_{i t-1}+\beta_{6} G R O W_{i t-1} \\
& +\beta_{7} P E_{\text {ER }} F_{i t-1}+\beta_{8} I_{N T E R_{i t-1}}+\varepsilon_{i t}
\end{aligned}
$$

Where:

Rating $_{i t}=$ credit rating of firm $\mathrm{i}$ in year $\mathrm{t}$;

$\alpha$ is the constant and $\beta$ is the estimated coefficient of the regression;

$B T D_{\text {it- } 1}=$ book-tax difference of firm $\mathrm{i}$ in year $\mathrm{t}-1$;

$\log \mathrm{A}_{\mathrm{it}-1}=\log$ of total assets of firm $\mathrm{i}$ in year $\mathrm{t}-1$;

$\mathrm{BIG}_{\mathrm{it}-1}=$ investment grade classification of Brazil in year $\mathrm{t}-1$;

$L E V_{\text {it }-1}=$ financial leverage of firm $\mathrm{i}$ in year $\mathrm{t}-1$;

$P R O F_{i t-1}=$ profitability of firm $\mathrm{i}$ in year $\mathrm{t}-1$

$G R O W_{i t-1}=$ growth of sales revenue of firm i from year $\mathrm{t}-2$ to $\mathrm{t}-1 \mathrm{t}-1$;

$P E R F_{i t-1}=$ financial market performance of firm $\mathrm{i}$ in year $\mathrm{t}-1$;

INTER $_{\text {it- }}=$ internationalization of firm $\mathrm{i}$ in year $\mathrm{t}-1$;

$\varepsilon_{i t}=$ residual of the regression for firm $\mathrm{i}$ in year $\mathrm{t}-1$.

Chart 2 presents the methods used to determine each variable in the proposed model.

\begin{tabular}{|c|c|}
\hline VARIABLE & DETERMINATION OF THE VARIABLE \\
\hline Rating $_{\text {it }}$ & Credit rating disclosed on the issuance of bonds. \\
\hline BTD $_{\text {it-1 }}$ & $\begin{array}{l}\text { Calculated by the difference between EBIT and taxable income, with EBIT being obtained by } \\
\text { dividing taxes on profits (IRPJ and CSLL) by the rate of } 34 \% \text {, scaled by total assets at t-1, as } \\
\text { done by Ferreira (2012). }\end{array}$ \\
\hline $\log \mathrm{A}_{\mathrm{it}-1}$ & Natural logarithm of total assets. \\
\hline $\mathrm{BIG}_{\mathrm{it}-1}$ & $\begin{array}{l}\text { Dummy variable, with value } 1 \text { for ratings in years when Brazil had investment grade } \\
\text { classification and } 0 \text { in other years. }\end{array}$ \\
\hline $\mathrm{LEV}_{\text {it-1 }}$ & Calculated by dividing the sum of current and long-term assets by total assets. \\
\hline
\end{tabular}

Chart 2 - Determination of the variables 


\begin{tabular}{|c|c|}
\hline PROF $_{\text {it-1 }}$ & Calculated by dividing net profit by stockholders' equity. \\
\hline GROW $_{\text {it-1 }}$ & Growth of sales revenue of firm $\mathrm{i}$ from year t- 2 to t- 1. \\
\hline PERF $_{\text {it-1 }}$ & Calculated by dividing market value by stockholders' equity. \\
\hline INTER $_{\text {it-1 }}$ & Dummy variable with value 1 for firms that issued ADRs and 0 for other firms. \\
\hline
\end{tabular}

Source: Prepared by the authors.

\subsubsection{Model 2 - Propensity to engage in earnings management and tax management as a determinant of credit rating}

To test $\mathrm{H}_{2}$, we used the same model proposed to test $\mathrm{H}_{1}$, but substituted $\mathrm{BTD}_{\mathrm{t}-1}$ by the propensity of manage earnings (EM dummyt-1) and taxes (TM dummyt-1).

Therefore, to analyze the determination of credit rating by the propensity to engage in earnings and tax management, we used the following model:

$$
\begin{gathered}
\text { Rating }_{i t}=\beta_{0}+\beta_{1} E M \text { dummy }_{i t-1}+\beta_{2} T M d u m m y_{i t-1}+\beta_{3} \log A_{i t-1} \beta{ }_{4} B I G_{i t-1}+\beta_{5} L E V_{i t-1}+\beta_{6} P R O F_{i t-1} \\
+\beta_{7} G R O W_{i t-1}+\beta_{8} P E R F_{i t-1}+\beta_{9} I N T E R_{i t-1}+\varepsilon_{i t}
\end{gathered}
$$

Where:

Rating $_{i t}=$ credit rating of firm i in year $\mathrm{t}$;

$\alpha$ is the constant and $\beta$ is the estimated coefficient of the regression;

$E M$ dummy $_{\mathrm{it}-1}=$ proxy for earnings management of firm i in year $\mathrm{t}-1$;

$T M$ dummy $_{\mathrm{it}-\mathrm{l}}=$ proxy of tax aggressiveness of firm $\mathrm{i}$ in year $\mathrm{t}-1$;

$\log \mathrm{A}_{\mathrm{it}-1}=\log$ of total assets of firm $\mathrm{i}$ in year $\mathrm{t}-1$;

$\mathrm{BIG}_{\mathrm{it}-1}=$ investment grade classification of Brazil in year $\mathrm{t}-1$;

$L E V_{\mathrm{it}-1}=$ financial leverage of firm $\mathrm{i}$ in year $\mathrm{t}-1$;

$P R O F_{i t-l}=$ profitability of firm $\mathrm{i}$ in year $\mathrm{t}-1$

$G R O W_{i t-1}=$ growth of sales revenue of firm i from year $\mathrm{t}-2$ to $\mathrm{t}-1 \mathrm{t}-1$;

$P E R F_{i t-1}=$ financial market performance of firm $\mathrm{i}$ in year $\mathrm{t}-1$;

INTER $_{\text {it- }}=$ internationalization of firm $\mathrm{i}$ in year $\mathrm{t}-1$;

$\varepsilon_{i t}=$ residual of the regression for firm $\mathrm{i}$ in year $\mathrm{t}-1$;

Chart 3 presents th methods used to determine the variables of the second model.

\begin{tabular}{|c|c|}
\hline VARIABLE & DETERMINATION OF THE VARIABLE \\
\hline Rating $_{\text {it }}$ & $\begin{array}{l}\text { Credit rating disclosed on the issuance of bonds, converted into an ordinal classification from } \\
22 \text { to } 1 \text {, as shown in Table } 1 .\end{array}$ \\
\hline EM dummy it-1 & $\begin{array}{l}\text { Calculated through the residuals of the discretionary accruals model of Jones (1991), adjusted } \\
\text { for performance according to Kothari et al. (2005), assuming value of } 1 \text { for firms above the } \\
\text { 3rd quartile and } 0 \text { for other firms. }\end{array}$ \\
\hline TM dummy it-1 & $\begin{array}{l}\text { Calculated by dividing taxes on profit (IRPJ and CSLL) by EBIT, i.e., the effective tax rate, } \\
\text { assuming value of } 1 \text { for firms below the } 1 \text { st quartile and } 0 \text { for other firms. }\end{array}$ \\
\hline $\log \mathrm{A}_{\mathrm{it}-1}$ & Natural logarithm of total assets. \\
\hline $\mathrm{BIG}_{\mathrm{it}-1}$ & $\begin{array}{l}\text { Dummy variable, with value } 1 \text { for ratings in years when Brazil had investment grade } \\
\text { classification and } 0 \text { in other years. }\end{array}$ \\
\hline $\mathrm{LEV}_{\text {it-1 }}$ & Calculated by dividing the sum of current and non-current assets by total assets. \\
\hline $\mathrm{PROF}_{\mathrm{it}-1}$ & Calculated by dividing net profit by stockholders' equity. \\
\hline
\end{tabular}

Chart 3 - Determination of the variables 
BOOK-TAX DIFFERENCE, EARNINGS MANAGEMENT AND BOND RATINGS IN THE BRAZILIAN MARKET

\begin{tabular}{|c|c|}
\hline GROW $_{\text {it-1 }}$ & Growth of sales revenue of firm $\mathrm{i}$ from year $\mathrm{t}-2$ to $\mathrm{t}-1$. \\
\hline PERF $_{\mathrm{it}-1}$ & Calculated by dividing market value by stockholders' equity. \\
\hline INTER $_{\mathrm{it}-1}$ & Dummy variable with value 1 for firms that issued ADRs and 0 for other firms. \\
\hline
\end{tabular}

Source: Prepared by the authors.

As described in Chart 4, in calculating EMdummyit-1 we used the discretionary accruals model of Jones (1991), adjusted for performance according to Kothari (2005), Where:

$\mathrm{TAC}_{\mathrm{t}-1}=$ total accruals of firm $\mathrm{i}$ in year $\mathrm{t}-1$;

$\triangle \mathrm{SALES}_{\mathrm{it}-1}=$ variation of sales revenue of firm $\mathrm{i}$ from year $\mathrm{t}-2$ to $\mathrm{t}-1$, scaled by total assets at the start of the year;

$\Delta \mathrm{AR}_{\mathrm{it}-1}=$ variation of accounts receivable of firm from year $\mathrm{t}-2$ to $\mathrm{t}-1$, scaled by total assets at the start of the year;

$\mathrm{NCA}_{\text {it- } 1}=$ non-current assets in year $\mathrm{t}-1$ scaled by total assets of the previous year;

$\mathrm{ROA}_{\mathrm{it}-1}=$ return on assets, calculated as net profit before extraordinary items divided by total assets at the start of the year.

The independent variable TAC (total accruals) used in the performance-adjusted Jones model was calculated as follows:

Where:

$$
T A C_{i t-1}=\left[\left(\triangle A C_{\mathrm{it}-1}-\triangle P P E_{\mathrm{it}-1}\right)-\left(\Delta P C_{\mathrm{it}-1}-\Delta D i v_{\mathrm{it}-1}\right)-D e p r_{\mathrm{it}-1}\right] / A_{i t-2}
$$

$T A C_{i t-1}=$ total accruals of firm $\mathrm{i}$ in year $\mathrm{t}-1$;

$\triangle \mathrm{CA}_{\mathrm{it}-1}=$ variation of current assets of firm $\mathrm{i}$ from the end of year $\mathrm{t}-2$ to the end of year $\mathrm{t}-1$;

$\triangle \mathrm{PPE}_{\mathrm{it}-1}=$ variation of property, plant and equipment of firm $\mathrm{i}$ from the end of year $\mathrm{t}-2$ to the end of year $\mathrm{t}-1 \mathrm{t}-1$;

$\Delta C L_{\text {it-1 }}=$ variation of current liabilities of firm i from the end of year $\mathrm{t}-2$ to the end of year $\mathrm{t}-1$ $\mathrm{t}-1$

$\Delta$ Debt $_{\mathrm{it}-\mathrm{l}}=$ variation of short-term loans and financing of firm $\mathrm{i}$ from the end of year $\mathrm{t}-2$ to the end of year $\mathrm{t}-1 \mathrm{t}-1$;

Depr $_{\text {it }-1}=$ amount of depreciation and amortization expenses of firm i during year $\mathrm{t}-1$.

$\mathrm{A}_{\mathrm{it}-1}=$ total assets of firm $\mathrm{i}$ in year $\mathrm{t}-1$;

\subsection{Sample and data collection}

The sample was composed of companies with shares listed on the BM\&FBovespa that issued bonds in the period from 2004 to 2014 and had sufficient financial information published to calculate the variables.

We collected the data from the Economática ${ }^{\circledR}$ database, using the following filters: i) location country: Brazil; ii) type of asset: stock; iii) class: ON/PN (common/preferred); iv) exchange: BM\&FBovespa; v) active or canceled: active; vi) utilize consolidated data; vii) currency: thousands of reais; viii) financial statement date: December 31, 20XX.

In turn, we obtained the credit ratings from the announcements of bond issues available at the site of Anbima (Brazilian Association of Financial and Capital Market Entities), in the period from 2004 to 2014 .

\subsection{Treatment of the data}

During the period studied, we found 271 bond issue announcements, distributed by year as shown in Table 2 below. 
As can be seen, there was strong concentration of bond issue announcements in 2005, 2006 and 2007, corresponding to $48.34 \%$ of the total. Of these 271 announcements, 23 did not indicate a credit rating. In this respect, according to Resolutions 2,720/00 and 2,829/00 from the National Monetary Council (CMN), classification is optional in some cases.

Table 2 - Distribution of bond issues per year

\begin{tabular}{cccc} 
YEAR & NUMBER & YEAR & NUMBER \\
\hline 2004 & 33 & 2010 & 19 \\
2005 & 44 & 2011 & 6 \\
2006 & 45 & 2012 & 15 \\
2007 & 42 & 2013 & 14 \\
2008 & 26 & 2014 & 8 \\
2009 & 19 & TOTAL & 271 \\
\hline
\end{tabular}

Source: Prepared by the authors.

We dropped these observations from the sample, resulting in a sample of 248 observations, as in Table 3:

Table 3 - Summary of the credit ratings of bond issues

CREDIT RATING

\begin{tabular}{|c|c|c|}
\hline AAA or Aaa & 22 & 32 \\
\hline $\mathrm{AA}+$ or $\mathrm{Aa} 1$ & 21 & 25 \\
\hline $\mathrm{AA}$ or $\mathrm{Aa} 2$ & 20 & 34 \\
\hline AA- or Aa3 & 19 & 31 \\
\hline $\mathrm{A}+$ or $\mathrm{A} 1$ & 18 & 31 \\
\hline A or A2 & 17 & 51 \\
\hline $\mathrm{A}-$ or $\mathrm{A} 3$ & 16 & 19 \\
\hline $\mathrm{BBB}+$ or Baa 1 & 15 & 14 \\
\hline $\mathrm{BBB}$ or $\mathrm{Baa} 2$ & 14 & 7 \\
\hline BBB- or Baa3 & 13 & 1 \\
\hline $\mathrm{BB}+$ or $\mathrm{Ba} 1$ & 12 & 2 \\
\hline $\mathrm{BB}$ or $\mathrm{Ba} 2$ & 11 & 0 \\
\hline $\mathrm{BB}$ - or $\mathrm{Ba} 3$ & 10 & 0 \\
\hline $\mathrm{B}+$ or $\mathrm{B} 1$ & 9 & 0 \\
\hline $\mathrm{B}$ or $\mathrm{B} 1$ & 8 & 0 \\
\hline $\mathrm{B}-$ or $\mathrm{B} 3$ & 7 & 0 \\
\hline $\mathrm{CCC}+$ or Caa1 & 6 & 0 \\
\hline $\mathrm{CCC}$ or $\mathrm{Caa} 2$ & 5 & 1 \\
\hline $\mathrm{CCC}-$ or $\mathrm{Caa} 3$ & 4 & 0 \\
\hline $\mathrm{CC}$ or $\mathrm{Ca}$ & 3 & 0 \\
\hline $\mathrm{C}$ or $\mathrm{C}$ & 2 & 0 \\
\hline $\mathrm{D}$ & 1 & 0 \\
\hline \multicolumn{2}{|c|}{ TOTAL } & 248 \\
\hline
\end{tabular}

Source: Prepared by the authors.

Among these 248 observations we found some firms that launched more than one bond issue in a year, and others that had more than one rating for different series. In these cases, we 
chose the worst rating, based on the tendency of analysts to do the same, out of prudence. Therefore, we excluded 11 observations. Additionally, for 81 observations there was insufficient financial information in the Economática ${ }^{\circledR}$ database to calculate all our variables, and 50 observations pertained to financial institutions, which have specific accounting standards, making their numbers not comparable with those of other firms. Therefore, we excluded 131 observations from the sample.

Finally, for the variable TM, which represents the effective tax rate, we only considered observations with a result between 0 and 1 , so we excluded a further 10 observations. The final sample was composed of 96 observations, with practically all the firms having been classified as investment grade, as can be seen in Table 4:

Table 4 - Summary of the final sample

CREDIT RATING

ORDINAL CLASSIFICATION No. of Observations

\begin{tabular}{ccc}
\hline AAA or Aaa & 22 & 5 \\
AA+ or Aa1 & 21 & 10 \\
AA or Aa2 & 20 & 10 \\
AA- or Aa3 & 19 & 12 \\
A+ or A1 & 18 & 17 \\
A or A2 & 17 & 26 \\
A- or A3 & 16 & 7 \\
BBB + or Baa1 & 15 & 6 \\
BBB or Baa2 & 14 & 2 \\
BBB- or Baa3 & 13 & 0 \\
\hline BB+ or Ba1 & 12 & 1 \\
BB or Ba2 & 11 & 0 \\
BB- or Ba3 & 10 & 0 \\
B + or B1 & 9 & 0 \\
B or B1 & 8 & 0 \\
B- or B3 & 7 & 0 \\
CCC + or Caa1 & 6 & 0 \\
CCC or Caa2 & 5 & 0 \\
CCC- or Caa3 & 4 & 0 \\
CC or Ca & 3 & 0 \\
C or C & 2 & 0 \\
D & 1 & 0 \\
\hline TOTAL & & 96 \\
\hline So & &
\end{tabular}

Source: Prepared by the authors.

With respect to the treatment of the data obtained from the Economática ${ }^{\circledR}$ database, two small adjustments were made starting in 2010 in the nomenclature used. Therefore, the variable variation of non-current assets in the calculation of total accruals (ACT) was obtained as RealLT (realizable in the long term) from 2004 to 2009 and from 2010 onward as NonCurrAss (noncurrent assets). Likewise, the variable variation of available cash assets in calculating total accruals (ATC) was obtained from 2004 to 2009 as CashSTInv (cash and short-term investments) and from 2010 onward as CCEquiv (cash and cash equivalents). 


\section{RESULT ANALYSIS}

Interpreting the data an empirical analysis is necessary, and the first step consisted in calculate the descriptive statistics of the variables, as indicated in Table 5. In the preliminary analysis of the descriptive statistics, among the possible observations we highlight the BTD metric mainly shows positive values, meaning higher accounting than taxable income. This indicates most firms had a propensity to manage earnings and taxes, by increasing accounting income and reducing taxable income (FERREIRA et al., 2012).

Table 5 - Descriptive Statistics

\begin{tabular}{ccccccccc}
\hline VARIABLE & MEAN & MEDIAN & $\begin{array}{c}\text { STAND. } \\
\text { DEV. }\end{array}$ & VAR & MINIMUM & MAXIMUM & Q1 & Q3 \\
\hline RATING & 18.10 & 18.00 & 2.04 & 4.18 & 12.00 & 22.00 & 17.00 & 20.00 \\
BTD & 0.02 & 0.01 & 0.03 & 0.00 & -0.05 & 0.20 & 0.00 & 0.03 \\
BTD RTT & 0.01 & 0.00 & 0.02 & 0.00 & -0.03 & 0.08 & 0.08 & 0.08 \\
BTD T & 0.01 & 0.00 & 0.03 & 0.00 & -0.15 & 0.16 & 0.00 & 0.02 \\
EM dummy & 0.32 & 0.00 & 0.47 & 0.22 & 0.00 & 1.00 & 0.00 & 1.00 \\
EM & 0.00 & -0.01 & 0.15 & 0.02 & -0.59 & 0.71 & -0.06 & 0.05 \\
EM abs & 0.09 & 0.06 & 0.12 & 0.01 & 0.00 & 0.71 & 0.02 & 0.09 \\
TM & 0.29 & 0.29 & 0.13 & 0.02 & 0.10 & 0.86 & 0.22 & 0.33 \\
TM dummy & 0.25 & 0.00 & 0.44 & 0.19 & 0.00 & 1.00 & 0.00 & 0.25 \\
LEV & 0.67 & 0.65 & 0.19 & 0.04 & 0.13 & 1.09 & 0.55 & 0.79 \\
PROF & 0.30 & 0.23 & 0.31 & 0.10 & -0.24 & 2.33 & 0.13 & 0.38 \\
SIZE & 6.69 & 6.63 & 0.44 & 0.20 & 5.76 & 7.73 & 6.40 & 7.05 \\
GROW & 0.14 & 0.09 & 0.19 & 0.04 & -0.03 & 1.30 & 0.05 & 0.17 \\
PERF & 3.04 & 1.92 & 4.13 & 17.08 & -5.95 & 25.43 & 1.31 & 3.18 \\
INTERN & 0.20 & 0.00 & 0.40 & 0.16 & 0.00 & 1.00 & 0.00 & 0.00 \\
BIG & 0.42 & 0.00 & 0.50 & 0.25 & 0.00 & 1.00 & 0.00 & 1.00 \\
\hline SOurce Prepared & & & & & & & & \\
\hline
\end{tabular}

Source: Prepared by the authors.

Table 6 presents the results obtained from the equation of discretionary accruals of Jones (1991), adjusted for performance according to Kothari et al. (2005). In turn, we used their residuals to calculate the dummy variable for EM, according to Chart 4, as presented in the methodology section (Section 3).

Table 6 - Discretionary Accruals

\begin{tabular}{ccc}
\hline VARIABLES & COEFFICIENTS & T-STAT \\
\hline 1/ASSETSt-1 & 166547.800 & $7.150^{* * *}$ \\
$\Delta$ SALESt-1- $\Delta$ ARt-1 & -0.059 & -0.902 \\
NCAt-1 & 0.147 & $3.094 * * *$ \\
ROAt-1 & 0.002 & 0.007 \\
Adjusted R & 0.391 & \\
Prob $>$ F & 0.000 & \\
Number of obs. & 96 & \\
\hline
\end{tabular}

This table presents the results of the model of Jones (1991) adjusted for performance according to Kothari et al. (2005). .**,** and * indicate statistical significance at $1 \%, 5 \%$ and $10 \%$, respectively.

Source: Prepared by the authors. 


\subsection{Results of model 1 - BTD as a determinant of credit rating}

Table 7 presents the results of Model 1 with all the variables (complete) and excluding the control variables not found to be significant at 10\% (adjusted), for the purpose of improving the proposed model:

Table 7 - Model 1 - BTD as a determinant of credit rating

\begin{tabular}{|c|c|c|c|c|}
\hline \multirow{2}{*}{ VARIABLE } & \multicolumn{2}{|c|}{ COMPLETE } & \multicolumn{2}{|c|}{ ADJUSTED } \\
\hline & COEFFICIENT & T-STAT & COEFFICIENT & T-STAT \\
\hline BTD & 4.319 & 0.775 & 3.782 & 0.748 \\
\hline $\log \mathrm{A}$ & 1.668 & $3.272 * * *$ & 1.711 & $\begin{array}{c}4.216^{* *} \\
*\end{array}$ \\
\hline BIG & 1.640 & $4.500 * * *$ & 1.640 & $\begin{array}{c}4.700^{* *} \\
*\end{array}$ \\
\hline LEV & -2.010 & $-1.955^{*}$ & -2.132 & $2.177 * *$ \\
\hline PROF & -0.006 & -0.009 & - & - \\
\hline GROW & -2.000 & $-1.876^{*}$ & -1.684 & $-1.728 *$ \\
\hline PERF & 0.047 & 0.892 & - & - \\
\hline INTERN. & 0.174 & 0.316 & - & - \\
\hline Adjusted $\mathrm{R}^{2}$ & \multicolumn{2}{|c|}{0.328} & \multicolumn{2}{|l|}{0.342} \\
\hline Prob $>$ F & \multicolumn{2}{|c|}{0.000} & \multicolumn{2}{|l|}{0.000} \\
\hline Number of obs. & \multicolumn{2}{|c|}{96} & \multicolumn{2}{|l|}{96} \\
\hline
\end{tabular}

This table presents the results of Model 1 (complete): Ratingit $=\beta_{0}+\beta_{1} \mathrm{BTD}_{\mathrm{it}-1}+\beta_{2} \log \mathrm{A}_{\mathrm{it}-1}+\beta_{3} \mathrm{BIG}$ it- $1+\beta_{4} \mathrm{LEV}_{\mathrm{it}-}$ ${ }_{1}+\beta_{5}$ PROF $_{\text {it }-1}+\beta_{6}$ GROW $_{\text {it- } 1}+\beta_{7}$ PERF $_{\text {it- } 1}+\beta_{8}$ INTER $_{\text {it- } 1}+\varepsilon_{\text {it }}$, and Model 1 (adjusted): Ratingit $=\beta_{0}+\beta_{1}$ BTD $_{\text {it- }}$

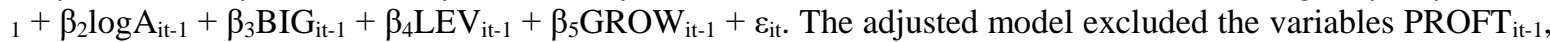
$\mathrm{PERF}_{\mathrm{it}-1}$ e INTER $\mathrm{INT}-1 .^{* * *}, * *$ and $*$ indicate statistical significance at $1 \%, 5 \%$ and $10 \%$, respectively.

Source: Prepared by the authors.

The results of Model 1 do not provide evidence that differences between book and taxable income determine the credit rating, thus not confirming $\mathrm{H}_{1}$. However, we point out that all the control variables of Model 1 (adjusted) are significant except for $\mathrm{GROW}_{\mathrm{t}-1}$, confirming the prediction of the sign for determination of credit rating, as indicated in Chart 3 of the methodology section (Section 3).

This finding runs contrary to others reported in the literature, in which various studies have shown the utility of BTD, such as in predicting financial difficulties (Schnader \& Noga, 2013), persistence and deterioration of earnings (Phillips et al., 2003; Hanlon, 2005; Blaylock et al., 2012), indication of earnings and tax management (TANG, 2006; FORMIGONI, ANTUNES \& PAULO, 2009) and profits growth (JACKSON, 2009).

Specifically regarding analysis of credit ratings, we mention the article of Ayres, Laplante and McGuire (2010), who showed evidence that both positive and negative variations in BTD are factors influencing credit rating downgrades in the American market. We were unable to employ this method due to the limitation of the sample, so we focused on analyzing the determination of the rating by the level of BTD rather than its variation.

Nevertheless, according to Weber (2009), the market tends to underestimate the risks involved in high BTDs, causing them not to be correctly priced. Our results corroborate this finding. 


\subsection{Results of Model 2 - Propensity for earnings and tax management as determinants of credit rating}

Table 8 reports the results of Model 2, with all the variables (complete) and excluding the control variables not found to be significant at 10\% (adjusted), for the purpose of improving the proposed model:

Table 8 - Model 2 - EMdummy and TMdummy as determinants of credit rating

\begin{tabular}{|c|c|c|c|c|}
\hline \multirow{2}{*}{ VARIABLE } & \multicolumn{2}{|c|}{ COMPLETE } & \multicolumn{2}{|c|}{ ADJUSTED } \\
\hline & COEFFICIENT & STAT $^{T}$ & COEFFICIENT & T-STAT \\
\hline EMdummy & -1.020 & $-2.401 * *$ & -1.133 & $-2.780^{* *}$ \\
\hline TMdummy & 0.233 & 0.570 & 0.228 & 0.568 \\
\hline $\log \mathrm{A}$ & 2.017 & $3.982 * * *$ & 2.035 & $5.158^{* * *}$ \\
\hline BIG & 1.611 & $4.510 * * *$ & 1.634 & $4.758 * * *$ \\
\hline LEV & -2.433 & $-2.427 * *$ & -2056 & $-2.251 * *$ \\
\hline PROF & 0.186 & 0.292 & - & - \\
\hline GROW & -1.390 & -1.313 & - & - \\
\hline PERF & 0.029 & 0.569 & - & - \\
\hline INTERN & -0.072 & -0.133 & - & - \\
\hline Adjusted $\mathrm{R}^{2}$ & \multicolumn{2}{|c|}{0.359} & \multicolumn{2}{|c|}{0.375} \\
\hline Prob $>F$ & \multicolumn{2}{|c|}{0.000} & \multicolumn{2}{|c|}{0.000} \\
\hline Number of obs. & \multicolumn{2}{|c|}{96} & \multicolumn{2}{|c|}{96} \\
\hline
\end{tabular}

This table presents the results of Model 2 (complete): Rating ${ }_{i t}=\beta_{0}+\beta_{1}$ EMdummy $_{\text {it }-1}+\beta_{2}$ TMdummy $_{\mathrm{it}-1}+\beta_{3} \log \mathrm{A}_{\mathrm{it}-1}+\beta_{4} \mathrm{BIG}$ it${ }_{1}+\beta_{5} \mathrm{LEV}_{\mathrm{it}-1}+\beta_{6} \mathrm{PROF}_{\mathrm{it}-1}+\beta_{7} \mathrm{GROW}_{\mathrm{it}-1}+\beta_{8} \mathrm{PERF}_{\mathrm{it}-1}+\beta_{9} \mathrm{INTER}_{\mathrm{it}-1}+\varepsilon_{\mathrm{it}}$, and Model 2 (adjusted): Rating it $_{\text {it }}=\beta_{0}+\beta_{1} \mathrm{EMdummy}_{\mathrm{it}-}$ ${ }_{1}+\beta_{2}$ TMdummy $_{\mathrm{it}-1}+\beta_{3} \log \mathrm{A}_{\mathrm{it}-1}+\beta_{4} \mathrm{BIG}_{\mathrm{it}-1}+\beta_{5} \mathrm{LEV}_{\mathrm{it}-1}+\varepsilon_{\mathrm{it}}$. The adjusted model excluded the variables PROFT $\mathrm{Pt}_{\mathrm{it}-1}, \mathrm{GROW}_{\mathrm{it}-1}$, $\mathrm{PERF}_{\mathrm{it}-1}$ and INTER $\mathrm{INt}_{\mathrm{in}} . * * *, * *$ and $*$ indicate statistical significance at $1 \%, 5 \%$ and $10 \%$, respectively.

Source: Prepared by the authors.

The results of Model 2 partially confirm $\mathrm{H}_{2}$, since at $5 \%$ significance the firms with propensity for earnings management to increase profit (EMdummyt $y_{t-1}$ ) were penalized with lower ratings, although a propensity for tax management (TMdummyt-1) did not have a significant effect on rating.

Therefore, this result indicates that the analysts of ratings agencies interpret the use of earnings management by firms as a risk factor to solvency, and thus assign lower credit ratings. However, this same risk is not perceived to be associated with tax aggressiveness. A possible explanation for this is Brazil's tax system. The tax management metric used here is only based on taxes on income, while the overall tax burden of firms includes other federal levies plus those at the state and municipal levels, all of which vary greatly depending on the firm's main sector of activity (industry, commerce and/or services).

Among the control variables in Model 2 (adjusted), we stress the statistical significance

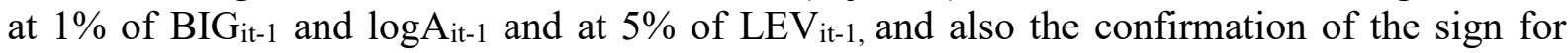
determination of the rating, according to Chart 4, as presented in the methodology section (Section 3).

\section{CONCLUSION}

The aim of this study was to investigate whether the credit ratings on the issuance of bonds in the Brazilian market from 2004 to 2014 were influenced by book-tax differences. Additionally, we investigated whether there was any influence of earnings and tax management. 
The results of the regressions indicate that book-tax differences did not determine credit ratings in the period studied. This finding runs counter to the literature published since the start of this century, in which many articles have reported the relevance of the information contained in BTD. More specifically, Ayres et al. (2010) presented evidence that variations in BTDs can negatively affect firms' credit ratings in the American market, although they analyzed the influence of variation of BTD instead of the level of this metric.

Corroborating this result, the robustness tests confirmed the result found in Model 1, showing that the RTT did not affect the relevance of this study, and the discretionary differences between book and taxable income, represented by TBTD, also did not act as a significant factor determining credit ratings.

However, the results of the regressions indicate firms with propensity to manage earnings upward are penalized with lower credit ratings, evidencing analysts interpret this behavior as a solvency risk factor of Brazilian firms. Additionally, the results of the robustness tests, besides confirming this result, indicate not only are firms that are more aggressive in managing earnings penalized, but the simple fact of managing earnings upward also brings this penalty. This finding also indicates analysts do not see downward management of earnings as a solvency risk factor.

The robustness tests, not reported in this working paper by limitation of space, also indicate firms that more aggressively manage earnings, whether to increase or decrease them, are not penalized, thus confirming that analysts interpret the fact that managers tend to increase earnings as a solvency risk factor, regardless of the level.

Finally, the results both of the regressions and robustness tests provide evidence the propensity to manage taxes does not have an effect on credit ratings in the Brazilian market.

As it is the case of all studies, this one has some limitations, mainly the small sample size, with only 96 observations. For future studies we suggest using corporate credit ratings over longer periods and with larger samples, as well as the inclusion of other metrics to calculate earnings management through discretionary accruals.

\section{REFERÊNCIAS}

AHMED, A.; BILLINGS, B., MORTON, R., STANFORD-HARRIS, M. The role of accounting conservatism in mitigating bondholder-shareholder conflicts over dividend policy and in reducing debt costs. Accounting Review. v.77, n.4, p. 867-890, 2002.

AYERS, BENJAMIN C.; LAPLANTE, STACIE K.; MCGUIRE, SEAN T. Credit Ratings and Taxes: The Effect of Book/Tax Differences on Ratings Changes. Contemporary Accounting Research. v.27, n. 2, p. 359-402, 2010.

BLUME, M.E., LIM, F.; MACKINLAY, A. C. The declining credit quality of U.S. corporate debt: Myth or reality? Journal of Finance. v.53, n.4, p.1389-1413, 1998.

CALLADO, ANTÔNIO. A. C.; VASCONCELOS, MÉRCIA. M. F.;RODRIGUES, RAIMUNDO. N.; \& LIBONATI, GERONYMO. O impacto da primeira emissão de conceito de risco crédito sobre os preços das ações: um estudo empírico sobre a reação do mercado acionário brasileiro para o setor bancário. Revista Ciências Administrativas, v.14, n.1, p. 80$88,2008$.

CALDERONI, FEDERICO; COLLO, PAOLO; GATTI, STEFANO. Ratings changes: the European evidence [Working Paper]. Social Science Research Network. Disponível em: http://ssrn.com/abstract=1410646. 2009.

CHENG, M.; SUBRAMANYAM, K.R. Analyst following and credit ratings. Contemporary Accounting Research. v.25, n.4, p. 1007-1044, 2008. 
CHI, SABRINA S.; PINCUS, M.; TEOH, SIEW H. Mispricing of Book-Tax Differences and the Trading Behavior of Short Sellers and Insiders.The Accounting Review. v. 27, n. 3, p. 469489, 2013.

FRANCIS, J.; LAFOND, R.; OLSSON, P.; SCHIPPER, K. The market pricing of accruals quality. Journal of Accounting and Economics. v.39, n.2, p. 295-327, 2005.

FERREIRA, F. R.; MARTINEZ, A. L.; COSTA, F. M.; PASSAMANI, R. R. Book-TaxDifferences e Gerenciamento de Resultados no Mercado de Ações do Brasil. RAE. v. 52, n. 5. p. 488-501, 2012.

FORMIGONI, H.; ANTUNES, M. T. P.; PAULO, E. Diferença entre o lucro contábil e o lucro tributável: uma análise sobre o gerenciamento de resultados contábeis e gerenciamento tributário nas companhias abertas brasileiras. Brazilian Business Review, v. 6, n. 1, p. 44-61, 2009.

GIL, A. C. Como elaborar projetos de pesquisa. 4. ed. São Paulo: Atlas, 2008.

GRAHAM, J.R; RAEDY, J.S; SCHACKELFORD, D.A. Research in accounting for income taxes. Journal of Accounting and Economics, v. 53, n. 1-2, p. 412-434, 2012.

GRAY, S.; MIRKOVIC, A.; RAGUNATHAN, V. (2006). The determinants of credit ratings: Australian evidence. Australian Journal of Management, v.31, n.2, p.333-354. DOI: 10.1177/031289620603100208.

HANLON, M. The persistence and pricing of earnings, accruals, and cash flows when firms have large book-tax differences. The Accounting Review, v. 50, n.1, p. 137-166, 2005.

HAND, J. R. M.; HOLTHAUSEN, LEFTWICH, R. W. Effect of bond rating agency announcements on bond and stock prices. The Journal of Finance. v.47, n.2, p.733-752, 1992.

KIM H.; GU, Z. Financial determinants of corporate bond ratings: an examination of hotel and casino firms. Journal of Hospitality \& Tourism Research, v. 28, n.1, 95-108, 2004. DOI: $10.1177 / 1096348003261217$.

LEV, B.; D. NISSIM. Taxable income, future earnings, and equity values. The Accounting Review. v.79, n.4, p.1039-1074, 2004.

MARTINEZ, A.L; PASSAMANI, R.R. Book-Tax-Differences e sua relevância informacional no mercado de capitais no Brasil. Revista de Gestão, Finanças e Contabilidade, v. 4, n. 2, p. 20-37, mai./ago., 2014.

; Souza, T.B.T. Book-tax-differences, earnings persistence and tax planning before and after the adoption of IFRS in Brazil. IX Congresso ANPCONT. 2015.

MURCIA, F.C.S; MURCIA, F.D; ROVER, S; BORBA, J.A. 2014. The Determinants of Credit Rating: Brazilian Evidence. BAR, Rio de Janeiro, v. 11, n. 2, art. 4, p. 188-209, Apr./June 2014.

NOGA, TRACY J.; SCHNADER, ANNE L.Book-Tax Differences as an Indicator of Financial Distress. Accounting Horizons v. 27, n. 3, p. 469-489, 2013.

STANDARD \& POOR'S RATINGS SERVICES. (2011). Guide to credit rating essentials: what are credit ratings and how do they work? Disponível em $<$ http://img.en25.com/Web/StandardandPoors/SP_CreditRatingsGuide.pdf $>$. Acesso em 20 de Abril de 2015.

WEBER, D. Do analysts and investors fully appreciate the implications of book-tax differences for future earnings? Contemporary Accounting Research, v. 26, n. 4, p. 1175-1206, 2009. 
ZIEBART, D. A., RIETER, S. A. Bond ratings, bond yields and financial information. Contemporary Accounting Research. v.9, n.1, p. 252-82, 1992. 